\title{
Penerapan Model Learning Cycle Untuk Meningkatkan Tanggung Jawab Siswa (PTK Pada Kelas V SD Negeri 11 Kota Bengkulu)
}

\author{
Wulanda Rahmadia \\ Universitas Bengkulu \\ wulandarah@gmail.com
}

\author{
Alexon \\ Universitas Bengkulu \\ alexon@unib.ac.id \\ Sri Dadi \\ Universitas Bengkulu \\ Srid3154@gmail.com
}

\begin{abstract}
This research aims to increase the responsibility of students in grade $V$ to Negeri 11 Bengkulu by applying the Learning Cycle learning model. This research is a classroom action research. The subjects of this study were 28 students consisting of 14 male students and 14 female students. The research procedure is in the form of a cycle. Each cycle consists of four stages including planning, implementing actions, observing and reflecting. The research instrument was in the form of observation sheets of teacher and student activities. The data analysis technique used is the observation sheet using the formula of the average score, the highest score, the lowest score, the difference in score and the range of values for each criterion. Thus the application of the Learning Cycle model can increase the responsibility of VB grade students in Sd Negeri 11 Bengkulu City.
\end{abstract}

Keywords: Learning Cycle Model, Responsibility.

\section{Pendahuluan}

Pengembangan karakter dan jati diri bangsa merupakan cita-cita leluhur yang harus diwujudkan melalui pendidikan yang terarah dan berkelanjutan. Penanaman nilai-nilai akhlak moral, dan budi pekerti seperti tertuang dalam Undang - Undang No. 20 Tahun 2003 Tentang Sistem Pendidikan Nasional Pasal3 menjelaskan bahwa pendidikan nasional berfungsi mengembangkan kemampuan dan membentuk watak serta peradaban bangsa yang bermartabat dalam rangka mencerdaskan kehidupan bangsa, bertujuan untuk berkembangnya potensi peserta didik agar menjadi manusia yang beriman dan bertakwa kepada Tuhan Yang Maha Esa, berakhlak mulia, sehat, berilmu, cakap, kreatif, mandiri, dan menjadi warga negara yang demokratis serta bertanggung jawab. Pernyataan tersebut menunjukkan bahwa pentingnya suatu pelaksanaan pendidikan yang seharusnya dilaksanakan secara merata dan menyeluruh. Hal ini disebabkan karena pendidikan merupakan salah satu faktor penting yang menjadi penunjang keberhasilan suatu bangsa.

Untuk menyelengarakan pendidikan diperlukan suatu pedoman atau acuan yaitu pedoman Kurikulum 2013. Kurikulum 2013 menekankan pada pendidikan 
karakter yang bertujuan untuk membina karakter peserta didik, Implementasi kurikulum 2013 yang berbasis karakter diharapkan dapat menjadikan siswa lebih mandiri meningkatkan dan menggunakan pengetahuan yang dimiliki tentang nilainilai karakter dan akhak mulia sehingga terwujud dalam prilaku sehari-hari. salah satu karakter sikap yang dikembangkan dalam kurikulum 2013 adalah tanggung jawab.

Muhamad Yaumi (2014: 114) menyatakan bahwa tanggung jawab adalah sikap dan prilaku seseorang untuk melaksanakan tugas dan kewajibannya, yang seharusnya dia lakukan, terhadap diri sendiri, masyarakat, lingkungan, dan Tuhan Yang Maha Esa. Menurut Lickona (2013:95) tanggung jawab adalah peduli terhadap diri sendiri dan orang lain, melaksanakan kewajiban, memberikan kontribusi terhadap masyarakat, meringankan perintah orang lain, dan menciptakan dunia yang lebih baik. Tanggung jawab merupakan suatu aspek yang sangat penting bagi manusia. Dengan adanya tanggung jawab yang tinggi akan mendorong seseorang untuk bersungguh-sungguh dalam melaksanakan dan menyelesaikan suatu pekerjaan dengan baik.

Berdasarkan hasil observasi di kelas V Sekolah Dasar Negeri 11 Kota Bengkulu, peneliti menemukan bahwa kurangnya tanggung jawab siswa di kelas VB dalam proses pembelajaran. Hal tersebut terlihat pada saat guru meminta siswa untuk membuat poster tentang hemat listrik secara berkelompok, akan tetapi siswa kurang mampu berkerjasama dengan kelompok, sehingga di dalam kelompok yang terdiri dari lima orang siswa hanya satu dua orang yang mengerjakan tugas tersebut, juga pada saat melaksanakan pembelajaran dengan cara membaca bergilir bacaan yang ada di LKS ada beberapa siswa yang tidak memperhatikan. Hal ini dapat di lihat saat siswa lain mendapat giliran membaca dengan cara ditunjuk oleh guru, siswa tersebut menanyakan sampai dimana bacaan yang telah dibaca. Selain itu siswa kurang tertib terhadap aturan sekolah, Saat peneliti melakukan pengamatan di kelas VB, terdapat beberapa peserta didik yang tidak melaksanakan tugasnya untuk piket kelas.

Rendahnya tanggug jawab siswa disebabkan belum tepatnya metode yang digunalam oleh guru, kurangnya stimulasi yang dapat meningkatkan tanggung jawab siswa, sehingga tanggung jawab siswa masih sangat kurang, pada saat siswa diberikan tugas secara kelompok hanya beberapa siswa saja yang mengerjakan tugas. Alasan kenapa siswa memiliki tanggung jawab yang rendah karena belum tepatnya metode yang digunakan oleh guru dan dari siswa itu sendiri.

Salah satu upaya Untuk meningkatkan tanggung jawab siswa dalam pembelajaran, peneliti menggunakan model pembelajaran yang efektif yaitu model pembelajaran Learning cycle. Model pembelajaran learning cycle adalah suatu model pembelajaran yang memiliki karakteristik berpusat pada siswa (student Centered) yang menitikberatkan pada aktivitas siswa, dan pengalaman mereka sendiri dengan terlibat secara aktif, sehingga siswa dapat menguasai kompetensi-kompetensi yang harus dicapai dalam pembelajaran dan melatih tanggung jawab siswa.

Model pembelajaran leraning cycle memungkinkan siswa untuk mampu bertanggung jawab dalam pembelajaran, pernyataan tersebut sesuai dengan pendapat Shoimin (2014:58) yang menyatakan bahwa salah satu keunggulan model pembelajaran learing cycle yang berpusat pada siswa dapat melatih siswa untuk lebih aktif kreatif dan tanggung jawab.

Berdasarkan permasalahan di atas, peneliti mengangkat judul "Penerapan Model Pembelajaran Learning Cycle Untuk Meningkatkan Tanggung Jawab Siswa (Ptk Pada Kelas V SD Negeri 11 Kota Bengkulu).

\section{Metode}

jenis penelitian ini adalah Penelitian Tindakan Kela. Penelitian ini dilaksanakan di SDN 11 Jln. Kolonel Berlian, Malabero, kec. Teluk Segara, Kota Bengkulu. Tahun pelajaran 1019/2020 dengan jumlah siswa sebanyak 28 siswa. 
Penelitian ini dilaksanakan mulai tanggal 21 Februari untuk siklus pertama dan tanggal 25 februari untuk siklus ke dua.

Penelitian ini dilaksanakan untuk melihat perubahan dengan adanya peningkatan tanggung jawab siswa dengan melihat hasil observasi siswa dan guru. Dengan beracuan pada refleksi awal maka penelitian ini dilaksanakan dengan prosedur perencanaan (planning), aksi atau tindakan (acting), observasi (observing), dan refleksi (reflection).

Pada penelitian ini, peneliti menggunakan lembar observasi sebagai instrumen penelitian. Lembar observasi ini digunakan untuk mengumpulkan data dalam proses pembelajaran menggunakan model learning cycle. Lembar observasi ini terdiri dari lembar observasi aktivitas guru dan lembar observasi tangggung jawab peserta didik. Lembar observasi guru digunakan untuk melihat bagaimana aktivitas guru dalam pembelajaran menggunakan model leraning cycle. Sedangkan lembar observasi tanggung jawab siswa digunakan untuk mengamati tanggung jawab siswa saat proses pembelajaran menggunakan model learning cycle.

Data observasi digunakan untuk merefleksikan siklus yang telah dilakukan dan diolah secara deskriptif. Penentuan nilai untuk tiap kriteria menggunakan persamaan yaitu rata-rata skor, skor tertinggi, skor terendah, selisih skor dan kisaran nilai untuk tiap kriteria.

\section{Hasil}

a. Perencanaan Tindakan

Langkah awal yang dilakukan peneliti pada siklus pertama ini adalah menganalisis pembelajaran dan Kompetensi Dasar (KD) yang kemudian dijabarkan dan dikembangkan menjadi indikator-indikator yang harus dicapai siswa dalam proses pembelajaran. Pada siklus pertama ini pembelajaran yang akan disampaikan adalah pembelajaran 1, subtema 1 manusia dan lingkungan, tema 8 lingkungan sahabat kita

\section{b. Pelaksanaan Tindakan}

Penelitian ini dilaksanakan pada tanggal 21 Februari 2020. Materi pokok yang disampaikan adalah tentang peristiwa dalam teks non fiksi dan manfaat air bagi makhluk hidup pada mata pelajaran Bahasa Indonesia dan IPA. Materi ini disampaikan dengan alokasi waktu 4 x 35 menit (satu pertemuan) dengan menggunakan langkah-langkah pelaksanaan dari model pembelajaran Learning Cyce pada pembelajaran Tematik. Adapun langkah-langkah model pembelajaran Learning Cycle yang dilakukan adalah sebagai berikut:

Pada tahap angangment (pembangkitan minat) merupakan kegiatan yang memfokuskan perhatian siswa, merangsang pemikirannya, dan mengetahui pengalaman awalnya. Pada tahap ini, guru mencoba memusatkan perhatian siswa dengan cara memberikan gambar tentang materi yang akan dipelajari, memberikan pertanyaan tentang gambar yang telah disajikan, yang digunakan untuk membuka pengetahuan siswa dan mengembangkan rasa keingintahuan siswa. Pada saat guru mendemonstrasikan tentang proses siklus air menggunakan gelas, siswa terlihat antusias dan rasa ingin tahunya sangat terlihat. Hal ini sejalan dengan pendapat Bundura dalam Trianto (2011: 77), fase motivasi diberikan penguatan untuk suatu tingkah laku tertentu akan memotivasi pembelajar untuk terlibat.

Exploration (Eksplorasi), Pada tahap ini guru membentuk kelompok siswa sscara hetorogen menjadi 4-5 kelompok, kemudian guru meminta siswa membacakan petunjuk pengerjaan tugas, setelah siswa membacakan petunjuk pengerjaan tugas, guru melanjutkan menjelaskan tentang learning cycle dengan rinci. Pada saat guru menjelaskan tentang Learing Cycle, siswa terlihat antusias karena sebelumnya mereka belum pernah belajar dengan menggunakan model ini, seketika kelas pun menjadi ramai dengan pertanyaan penasaran. Setelah itu, siswa dengan bimbingan guru diberi kesempatan untuk bekerjasama dalam diskusi kelompok. Siswa mencoba alternatif pemecahannya dengan rekan sekelompoknya dan mencatat pengamatan 
serta ide-ide atau pendapat yang berkembang dalam diskusi. Hal ini sejalan dengan pendapat Pinto (2014) memberikan kesempatan kepada siswa untuk berfikir, mencari, menemukan dan menerapkan konsep yang dipelajari.

Explanation (penjelasan) Pada tahap ini guru membimbing siswa untuk menyampaikan hasil kegiatan yang telah mereka lakukan dengan menggunakan ide dan kata-kata mereka sendiri, sebelum siswa menyampaikan hasil kegiatan, guru meminta siswa untuk menentukan juru bicara dalam setiap kelompok, sehingga diharapkan siswa menjadi aktif dan pemahaman konsep muncul dari pengalaman mereka setelah melakukan kegiatan. Hal ini sejalan dengan pendapat Ngalimun (2014:) yang menyatakan bahwa model pembelajaran learning cycle merupakan kegiatan (fase) yang diorganisasi sedemikian rupa sehingga siswa dapat menguasai kompetensi yang harus di capai dalam pembelajaran dengan berperan aktif.

Elaboration (elaborasi) Pada tahap ini guru memfasilitasi siswa untuk dapat menerapkan konsep yang telah mereka peroleh berdasarkan kegiatan yang telah mereka lakukan ke dalam situasi atau masalah yang baru. Masalah baru tersebut memiliki penyelesaian yang identik atau apa yang dibahas sebelumnya. Kegiatan belajar ini mengarahkan siswa menerapkan konsep-konsep yang telah dipelajari melalui kegiata belajar lanjutan yang dapat memperkuat dan memperluas konsep yang telah dipelajari. Hal ini sejalan dengan pendapat Shoimin (2014: 61) yang menyatakan bahwa kelebihan model learning cycle adalah siswa dapat menerima pengalaman dan dimengerti oleh orang lain.

Evaluation (Evaluasi) Pada tahap ini guru memberikan soal latihan untuk menguji kemampuan siswa terhadap materi yang telah mereka pelajari, guru memberikan soal latihan secara individu, setelah semua siswa mendapatkan soal, guru memperingati siswa untuk tidak mencontoh pekerjaan temannya "kerjakan sendiri-sendiri, jangan ada yang mencontoh". Guru juga memberikan batas waktu kepada siswa untuk mengerjakan soal, setelah mengerjakan soal, untuk mengetahui pemahaman siswa tentang pelajaran guru meminta siswa mengaitkan apa yang telah mereka pelajari dengan situasi di kehidupan nyata, "kita sudah belajar tentang fungsi air, ibu mau tanya siapa yang masih ingat apa saja fugsi air bagi kehidupan?". Serentak siswa menjawab "untuk mandi buk" ada juga yang menjawab "untuk minum buk". gurupun memberi penguatan materi " betul ya, salah satu fungsi air dalam kehidupan yaitu untuk minum, untuk mandi, untuk menyiram tanaman dan masih banyak lainnya" Tahap ini guru dapat melihat pemahaman siswa dan menunjukkan sikap mereka tentang pembelajaran. Hal ini sejalan dengan pendapat Shoimin (2014:61) yang menyatakan bahwa kelebihan model Learning Cycle adalah menciptakan pembelajaran menjadi lebih bermakna.

c. Observasi

Hasil Observasi Aktivitas Guru Siklus Pertama Yang Dilakukan Oleh dua orang observer dalam satu kali pertemuan, memperoleh skor rata-rata sebesar 14, 5 dengan kategori cukup.

Hasil observasi aktivitas guru dalam setiap langkah model Learning Cycle dapat dilihat pada tabel berikut:

\begin{tabular}{|l|l|l|l|}
\hline Aspek yang diamai & \multicolumn{2}{|c|}{ Hasil Pengamatan } & \multirow{2}{*}{ Rata-rata } \\
\cline { 2 - 3 } & Observer 1 & Observer 2 & \\
\hline
\end{tabular}


Rahmadia, W., Alexon., Dadi, S.

\begin{tabular}{|l|l|l|l|}
\hline $\begin{array}{l}\text { Engagment (Pembangkitan } \\
\text { minat) }\end{array}$ & 3 & 3 & 3 \\
\hline Exploration (Eksplorasi) & 3 & 2 & 2,5 \\
\hline Explanation (Penjelasan) & 3 & 3 & 3 \\
\hline Elaboration (Elaborasi) & 3 & 3 & 3 \\
\hline Evaluation (Evaluasi) & 3 & 3 & 3 \\
\hline Jumlah skor & 15 & 14 & 14,5 \\
\hline \multicolumn{2}{|l|}{ Kategori } & & Cukup \\
\hline
\end{tabular}

Hasil observasi penilaian sikap tanggung jawab pengamat 1 mendapat nilai 783 dan pegamat 2 mendapat nilai 761 dengan rata-rata 27,52 termasuk ke dalam kategori cukup. Hasil pengamatan terlihat pada tabel di bawah ini:

\begin{tabular}{|l|c|c|}
\hline Data siklus pertama & Observer 1 & Observer 2 \\
\hline Jumlah skor & 783 & 761 \\
\hline Rata-rata observer 1 dan 2 & \multicolumn{2}{|c|}{27,52} \\
\hline Rata-rata kelas & Cukup \\
\hline Kategori & \\
\hline
\end{tabular}

\section{d. Refleksi}

Adapun refleksi pada siklus pertama sebagai berikut, guru harus membimbing siswa sebelum menjawab membiasakan menunjuk tangan terlebih dahulu, guru juga harus membiasakan siswa setelah memaca teks bacaan untuk menuliskan dan melaporkan peristiwa penting yang terdapat dalam teks bacaan. guru membimbinng siswa dalam kegiatan kelompok dan membagi siswa secara heterogen, guru juga harus mendatangi setiap kelompok dan menegur siswa-siswa yang tidak bekerjasama dalam kelompok agar dapat bekerjasama dan saling bertanggung jawab pada tugas yang diberikan. Guru memberikan penjelasan kepada siswa tentang maksud dan tujuan model pembelajaran learning cycle. Guru membimbing siswa dalam diskusi kelompok, guru juga harus mendatangi setiap kelompok dan menanyakan kepada siswa jika ada yang belum mereka pahami. Guru juga harus membiasakan siswa untuk menuliskan hasil diskusi di buku catatan. guru harus memberikan pemantapan materi pelajaran yang telah dipelajarai, guru juga harus memfasilitasi siswa untuk menerapkan pembelajraan yang telah mereka peroleh dan membimbing siswa menuliskan hasil kesimpulan di buku catatan. guru harus membimbing dan mengajak siswa untuk mengaitkan materi yang telah di pelajarai dengan kehidupan sehari-hari.

Siklus Kedua

a. Pelaksanaan Tindakan

Langkah awal yang dilakukan peneliti pada siklus pertama ini adalah menganalisis pembelajaran dan Kompetensi Dasar (KD) yang kemudian dijabarkan dan dikembangkan menjadi indikator-indikator yang harus dicapai siswa 
dalam proses pembelajaran. Pada siklus pertama ini pembelajaran yang akan disampaikan adalah pembelajaran 2, subtema 1 manusia dan lingkungan, tema 8 lingkungan sahabat kita

b. Pelaksanaan Tindakan

Penelitian ini dilaksanakan pada tanggal 21 Februari 2020. Materi pokok yang disampaikan adalah tentang peristiwa dalam teks fiksi dan siklus air pada mata pelajaran Bahasa Indonesia dan IPA. Materi ini disampaikan dengan alokasi waktu $4 \times 35$ menit (satu pertemuan) dengan menggunakan langkah-langkah pelaksanaan dari model pembelajaran Learning Cyce pada pembelajaran Tematik. Adapun langkah-langkah model pembelajaran Learning Cycle yang dilakukan adalah sebagai berikut:

Pada tahap angangment (pembangkitan minat) merupakan kegiatan yang memfokuskan perhatian siswa, merangsang pemikirannya, dan mengetahui pengalaman awalnya. Pada tahap ini, guru mencoba memusatkan perhatian siswa dengan cara memberikan gambar tentang materi yang akan dipelajari, memberikan pertanyaan tentang gambar yang telah disajikan, yang digunakan untuk membuka pengetahuan siswa dan mengembangkan rasa keingintahuan siswa. Pada saat guru mendemonstrasikan tentang proses siklus air menggunakan gelas, siswa terlihat antusias dan rasa ingin tahunya sangat terlihat. Hal ini sejalan dengan pendapat Bundura dalam Trianto (2011: 77), fase motivasi diberikan penguatan untuk suatu tingkah laku tertentu akan memotivasi pembelajar untuk terlibat.

Exploration (Eksplorasi), Pada tahap ini guru membentuk kelompok siswa sscara hetorogen menjadi 4-5 kelompok, kemudian guru meminta siswa membacakan petunjuk pengerjaan tugas, setelah siswa membacakan petunjuk pengerjaan tugas, guru melanjutkan menjelaskan tentang learning cycle dengan rinci. Pada saat guru menjelaskan tentang Learing Cycle, siswa terlihat antusias karena sebelumnya mereka belum pernah belajar dengan menggunakan model ini, seketika kelas pun menjadi ramai dengan pertanyaan penasaran. Setelah itu, siswa dengan bimbingan guru diberi kesempatan untuk bekerjasama dalam diskusi kelompok. Siswa mencoba alternatif pemecahannya dengan rekan sekelompoknya dan mencatat pengamatan serta ide-ide atau pendapat yang berkembang dalam diskusi. Hal ini sejalan dengan pendapat Pinto (2014) memberikan kesempatan kepada siswa untuk berfikir, mencari, menemukan dan menerapkan konsep yang dipelajari.

Explanation (penjelasan) Pada tahap ini guru membimbing siswa untuk menyampaikan hasil kegiatan yang telah mereka lakukan dengan menggunakan ide dan kata-kata mereka sendiri, sebelum siswa menyampaikan hasil kegiatan, guru meminta siswa untuk menentukan juru bicara dalam setiap kelompok, sehingga diharapkan siswa menjadi aktif dan pemahaman konsep muncul dari pengalaman mereka setelah melakukan kegiatan. Hal ini sejalan dengan pendapat Ngalimun (2014:) yang menyatakan bahwa model pembelajaran learning cycle merupakan kegiatan (fase) yang diorganisasi sedemikian rupa sehingga siswa dapat menguasai kompetensi yang harus di capai dalam pembelajaran dengan berperan aktif.

Elaboration (elaborasi) Pada tahap ini guru memfasilitasi siswa untuk dapat menerapkan konsep yang telah mereka peroleh berdasarkan kegiatan yang telah mereka lakukan ke dalam situasi atau masalah yang baru. Masalah baru tersebut memiliki penyelesaian yang identik atau apa yang dibahas sebelumnya. Kegiatan belajar ini mengarahkan siswa menerapkan konsep-konsep yang telah dipelajari melalui kegiata belajar lanjutan yang dapat memperkuat dan memperluas konsep yang telah dipelajari. Hal ini sejalan dengan pendapat Shoimin (2014: 61) yang menyatakan bahwa kelebihan model learning cycle adalah siswa dapat menerima pengalaman dan dimengerti oleh orang lain. 
Evaluation (Evaluasi) Pada tahap ini guru memberikan soal latihan untuk menguji kemampuan siswa terhadap materi yang telah mereka pelajari, guru memberikan soal latihan secara individu, setelah semua siswa mendapatkan soal, guru memperingati siswa untuk tidak mencontoh pekerjaan temannya "kerjakan sendiri-sendiri, jangan ada yang mencontoh". Guru juga memberikan batas waktu kepada siswa untuk mengerjakan soal, setelah mengerjakan soal, untuk mengetahui pemahaman siswa tentang pelajaran guru meminta siswa mengaitkan apa yang telah mereka pelajari dengan situasi di kehidupan nyata, "kita sudah belajar tentang fungsi air, ibu mau tanya siapa yang masih ingat apa saja fugsi air bagi kehidupan?". Serentak siswa menjawab "untuk mandi buk" ada juga yang menjawab "untuk minum buk". gurupun memberi penguatan materi " betul ya, salah satu fungsi air dalam kehidupan yaitu untuk minum, untuk mandi, untuk menyiram tanaman dan masih banyak lainnya" Tahap ini guru dapat melihat pemahaman siswa dan menunjukkan sikap mereka tentang pembelajaran. Hal ini sejalan dengan pendapat Shoimin (2014:61) yang menyatakan bahwa kelebihan model Learning Cycle adalah menciptakan pembelajaran menjadi lebih bermakna.

c. Observasi

Pada siklus ke dua memperoleh skor rata-rata hasil pengamatan penerapan model learning cycle sebesar 22 dengan kategori sangat baik. Hasil observasi aktivitas guru dalam setiap langkah model Learning Cycle dapat dilihat pada tabel berikut:

\begin{tabular}{|l|c|c|c|}
\hline \multirow{2}{*}{ Aspek yang diamai } & \multicolumn{2}{|c|}{ Hasil Pengamatan } & \multirow{2}{*}{ Rata-rata } \\
\cline { 2 - 3 } & Observer 1 & Observer 2 & \\
\hline Egagment & 5 & 4 & 4,5 \\
\hline Exploration & 5 & 4 & 4,5 \\
\hline Explanation & 4 & 4 & 4 \\
\hline Elaboration & 4 & 4 & 4 \\
\hline Evaluation & 5 & 5 & 5 \\
\hline Jumlah Skor & 23 & 21 & 22 \\
\hline
\end{tabular}

Pada hasil observasi penilaian sikap tanggung jawab siklus ke duapengamat 1 mendapatkan nilai 1.088 dengan rata-rata 38,45 termasuk ke dalam kategori sangat baik dan observasi yang dilakukan oleh pengamat 2 mendapatkan nilai 1.068 dengan rata-rata 38,45 termasuk ke dalam kategori sangat baik. Hasil pengamatan terlihat pada tabel berikut:

\begin{tabular}{|l|c|c|}
\hline Data siklus pertama & Observer 1 & Observer 2 \\
\hline Jumlah skor & 1.088 & 1.068 \\
\hline Rata-rata observer 1 dan 2 & \multicolumn{2}{|c|}{1.078} \\
\hline Rata-rata kelas & \multicolumn{2}{|c|}{38,45} \\
\hline
\end{tabular}


Rahmadia, W., Alexon., Dadi, S.

\begin{tabular}{|l|c|}
\hline Kategori & Sangat baik \\
\hline
\end{tabular}

\section{Pembahasan}

1. Penerapan Model Pembelajaran Learning Cycle

Berdasarkan permasalahan yang dipaparkan pada latar belakang penelitian ini, maka dilaksanakan penelitian tindakan kelas dengan menggunakan model pembelajaran Learning Cycle untuk meningkatan tanggung jawab siswa pada kelas VB Sekolah Dasar Negeri 11 Kota Bengkulu. Peneliti ini bertujuan untuk meningkatkan tanggung jawab siswa. Setelah dilaksanakan penelitian yang berlangsung dalam dua siklus hasil yang diperoleh yaitu penerapan model pembelajaran Learing Cycle dapat meningkatkan tanggung jawab siswa. Hal ini dibuktikan dengan adanya peningkatan skor tanggung jawab siswa dari siklus pertama ke siklus kedua.

Pada siklus pertama rata-rata skor tanggung jawab yang diperoleh siswa belum mencapai kriteria keberhasilan tindakan, sehingga peneliti ini dilanjutkan pada siklus kedua. Pada siklus kedua skor rata-rata yang diperoleh siswa menunjukkan peningkatkan dan sudah mencapai kriteria keberhasilan yang telah ditetapkan. Adapun langkah-langkah model pembelajaran Learning Cycle yang dilakukan adalah sebagai berikut:

Engagment, pada siklus pertama rata-rata 3 (cukup) dan pada siklus kedua memperloleh rata-rata 4,5 (sangat baik). Pada tahap pembangkitan minat merupakan kegiatan yang akan memfokuskan perhatian siswa, merangsang pemikirannya, dan mengetahui pengalaman awalnya. Pada tahap ini, guru mencoba memusatkan perhatian siswa dengan cara memberikan gambar tentang materi yang akan dipelajari, memberikan pertanyaan motivasi , demonstrasi, atau aktivitas lain yang digunakan untuk membuka pengetahuan siswa dan mengembangkan rasa keingintahuan siswa. Pada saat guru mendemonstrasikan tentang proses siklus air menggunakan gelas, siswa terlihat antusias dan rasa ingin tahunya sangat terlihat. Hal ini sejalan dengan pendapat Bundura dalam Trianto (2011: 77), fase motivasi diberikan penguatan untuk suatu tingkah laku tertentu akan memotivasi pembelajar untuk terlibat.

Exploration (Eksplorasi), pada siklus pertama memperoleh rata-rata 2,5 (kurang) meningkat pada siklus kedua memperoleh rata-rata 4,5 (sangat baik). Pada tahap ini siswa dibentuk kelompok kecil antara 4-5 kelompok, kemudian guru meminta siswa membacakan petunjuk pengerjaan tugas, setelah siswa membacakan petunjuk pengerjaan tugas, guru melanjutkan menjelaskan tentang learning cycle dengan rinci. Pada saat guru menjelaskan tentang Learing Cycle, siswa terlihat antusias karena sebelumnya mereka belum pernah belajar dengan menggunakan model ini, seketika kelas pun menjadi ramai dengan pertanyaan penasaran. Setelah itu, siswa dengan bimbingan guru diberi kesempatan untuk bekerjasama dalam diskusi kelompok. Siswa mencoba alternatif pemecahannya dengan rekan sekelompoknya dan mencatat pengamatan serta ide-ide atau pendapat yang berkembang dalam diskusi. Hal ini sejalan dengan pendapat Pinto (2014) memberikan kesempatan kepada siswa untuk berfikir, mencari, menemukan dan menerapkan konsep yang dipelajari.

Explanation (penjelasan), pada siklus pertama memperoleh rata-rata 3 (cukup) meningkat pada siklus kedua memperoleh rata-rata 4 (baik). Pada tahap ini guru membimbing siswa untuk menyampaikan hasil kegiatan yang telah mereka lakukan dengan menggunakan ide dan kata-kata mereka sendiri, sebelum siswa menyampaikan hasil kegiatan, guru meminta siswa untuk menentukan juru bicara dalam setiap kelompok, sehingga diharapkan siswa menjadi aktif dan pemahaman konsep muncul dari pengalaman mereka setelah melakukan kegiatan. Hal ini sejalan dengan pendapat Ngalimun (2014:) yang menyatakan bahwa model pembelajaran learning cycle merupakan kegiatan (fase) yang diorganisasi 
sedemikian rupa sehingga siswa dapat menguasai kompetensi yang harus di capai dalam pembelajaran dengan berperan aktif.

Elaboration (elaborasi), pada siklus pertama memperoleh rata-rata 3 (cukup) mengingatkan pada siklus kedua memperoleh rata-rata 4 (baik). Pada tahap ini guru memfasilitasi siswa untuk dapat menerapkan konsep yang telah mereka peroleh berdasarkan kegiatan yang telah mereka lakukan ke dalam situasi atau masalah yang baru. Masalah baru tersebut memiliki penyelesaian yang identik atau apa yang dibahas sebelumnya. Kegiatan belajar ini mengarahkan siswa menerapkan konsepkonsep yang telah dipelajari melalui kegiata belajar lanjutan yang dapat memperkuat dan memperluas konsep yang telah dipelajari. Hal ini sejalan dengan pendapat Shoimin (2014: 61) yang menyatakan bahwa kelebihan model learning cycle adalah siswa dapat menerima pengalaman dan dimengerti oleh orang lain.

Evaluation (Evaluasi) pada siklus pertama memperoleh rata-rata 3 (cukup) meningkat pada siklus kedua memperoleh rata-rata 5 (sangat baik). Pada tahap ini merupakan tahap saat guru mencari tahu kualitas dan kuantitas ketercapaian pemahaman peserta didik terhadap topik yang telah mereka pelajari. Guru mengajukan pertanyaan dan membuat peserta didik merespon secara lisan atau tulisan. Selain itu, siswa diminta untuk mengaitkan apa yang telah mereka pelajari dengan situasi di kehidupan nyata. Tahap ini adalah dimana siswa dapat menunjukkan sikap mereka tentang pembelajaran. Hal ini sejalan dengan pendapat Shoimin (2014:61) yang menyatakan bahwa kelebihan model Learning Cycle adalah menciptakan pembelajaran menjadi lebih bermakna.

Penerapan langkah-langkah model pembelajaran Learning Cycle dapat membuat siswa menjadi bertanggung jawab, hal ini terlihat pada saat pembelajaran berlangsung, siswa sudah mulai bertanggung jawab dengan tugas yang diberikan, siswa juga mengerjakan tugas dengan tepat waktu, dan bertanggung jawab dengan kebersihan kelas, hal ini sejalan dengan hasil penelitian Udayani (2014), dalam penelitiannya menyatakan bahwa Learning Cycle dapat melatih siswa unuk bertanggung jawab. Dengan penerapan langkah-langkah model Learning Cycle juga dapat melatih siswa menjadi aktif dan kreatif. Hal ini terlihat pada saat pembelajaran berlangsung, siswa sudah mulai aktif bertanya dan siswa juga tidak ragu-ragu menjawab pertanyaan dari guru, pada saat mengerjakan tugas kelompok siswa juga sudah mulai kreatif, siswa sudah berani mengeluarkan ide/ pendapat kepada teman kelompoknya. Hal ini sejalan dengan penelitian yang dilakukan oleh Elvionita (2019), dalam penelitiannya menyatakan bahwa model learning cycle membuat siswa dapat terlibat aktif dalam proses pembelajaran sehingga membentuk siswa yang aktif, inovatif dan kreatif serta pembelajaran menjadi lebih bermakna dan menyenangkan.

\section{Tanggung Jawab Siswa}

Hasil observasi tanggung jawab siswa diketahui bahwa hasil observasi tanggung jawab pada sembilan indikator tanggung jawab tersebut pada siklus pertama memperoleh rata-rata skor sebesar 27, 52 termasuk kategori cukup. Sedangkan hasil observasi tanggung jawab pada siklus kedua memperoleh rata-rata 38,45 berada pada kategori sangat baik.

Pada indikator tanggung jawab melaksanakan tugas secara mandiri pada siklus pertama memperoleh rata-rata skor 3,07 (cukup) pada siklus kedua meningkat dengan rata-rata 4,26 (sangat baik). Berdasarkan hasil obsevasi menunjukkan bahwa siswa sudah bertanggug jawab dengan melaksanakan tugas secara mandiri tanpa bantuan orang lain dan tidak mencontoh tugas temannya. Hal ini sejalan dengan Abdullah (2010:90) yang menyatakan bahwa tanggung jawab adalah kemampuan seseorang dalam melaksanakan kewajiban karena adanya dorongan dalam diri. 
Pada indikator tanggung jawab mampu mengatasi hambatan pada siklus pertama memperoleh rata-rata skor 3,10 (cukup) pada siklus kedua meningkat dengan rata-rata 4,26 (sangat baik). Berdasarkan hasil observasi peningkatan tanggung jawab siswa dapat dilihat saat siswa sudah mulai mandiri mengatasi hambatan pada saat pembelajaran berlangsung. Hal ini sejalan dengan Suyadi (2019:69) yang menyatakan bahwa individu yang memiliki tanggung jawab yang tinggi berani mengambil resiko kegagalan, dapat menjadi individu yang memiliki kreativitas dan mandiri.

Pada indikator bertanggung jawab terhadap tugas yang diberikan pada siklus pertama memperoleh rata-rata skor 3,5 (cukup) pada siklus kedua meningkat dengan rata-rata 4,33 (sangat baik). Berdasarkan hasil obeservasi siswa mampu bertanggung jawab terhadap tugas yang diberikan, siswa disiplin mengumpulkan tugas tepat waktu. Hal ini sejalan dengan Ulfa (2014) yang menyatakan bahwa tanggung jawab juga di tandai dengan adanya sikap disiplin dan empati.

Indikator tidak tergesa-gesa dalam melakukan sesuatu pada siklus pertama memperoleh rata-rata skor 3,8 (cukup) pada siklus kedua meningkat dengan ratarata 4,12 (baik). Berdasarkan hasil observasi peningkatan tanggung jawab siswa dapat dilihat saat siswa tidak tergesah-gesah dalam melakukan sesuatu. Siswa mampu mengerjakan tugas dengan tertib dan sesuai petunjuk yang diberikan. Hal ini sejalan dengan Lickona (2014: 77) yang menyatakan salah satu tujuan tanggung jawab yaitu mendengarkan dengan penuh perhatian, mengikuti arahan, dan tetap mengerjakan tugas.

Pada indikator memiliki inisiatif untuk belajar pada siklus pertama memperoleh rata-rata 3,12 (cukup) pada siklus kedua meningkat dengan rata-rata 4,37 (sangat baik). Berdasarkan hasil observasi siswa sudah memiliki inisiatif untuk belajar. Siswa sudah mulai aktif dalam proses pembelajaran. Hal ini sejalan dengan Saleh (2012:321) yang menyatakan bahwa tanggung jawab adalah tingkat kemampuan seseorang untuk menunjukkan respon dan kepedulian atas apa yang dilakukannya.

Pada indikator kreatif dalam hal positif pada siklus pertama memperoleh ratarata 2,96 (cukup) pada siklus kedua meningkat dengan rata-rata 4,19 (baik) . berdasarkan hasil observasi peningkatan tanggung jawab siswa dapat dilihat saat siswa mengeluarkan ide/ pendapat pada saat diskusi kelompok. Hal ini sejalan dengan Daryanto (2013:142) Yang menyatakan bahwa tanggung jawab merupakan kesadaran manusia akan tingkah laku atau perbuatan yang disengaja maupun tidak disengaja.

Indikator percaya diri terhadap kemampuan sendiri pada siklus pertama memperoleh rata-rata skor 2,94 (cukup) pada siklus kedua meningkat dengan ratarata 4, 32 (sangat baik). Berdasarkan hasil observasi penigkatan tanggung jawab siswa dapat dilihat pada saat siswa percaya dengan kemampuan sendiri, siswa juga sudah mampu menjadi pemimpin dalam kelompok. Hal ini sejalan dengan Zubaedi (2011:78) yang menyatakan bahwa orang yang bertanggung jawab memiliki komitmen yang tinggi, mandiri, dan menyelesaikan tugas dengan penuh rasa percaya diri.

Indikator mampu mengendalikan diri pada siklus pertama memperoleh ratarata skor 3,10 (cukup) pada siklus kedua meningkat dengan rata-rata skor 4,23 (sangat baik). Berdasarkan hasil observasi siswa sudah mampu mengendalikan diri. Hal ini terlihat pada saat siswa mampu menerima dan menghargai pendapat orang lain. Hal ini sejalan dengan penelitian yang di lakukan oleh Ulfa (2014) menyatakan bahwa tanggung jawab adalah prilaku yang menentukan bagaimana kita bereaksi terhadap situasi hari, yang memerlukan beberapa keputusan.

Indikator mampu bertindak dengan benar pada siklus pertama memperoleh rata-rata skor 3,10 (cukup) meningkat pada siklus kedua dengan rata-rata skor 4,37 (sangat baik). Berdasarkan hasil observasi peningkatan tanggung jawab siswa dapat dilihat pada saat pembelajaran berlangsung, siswa sudah mampu bertindak dengan benar, siswa juga saling tolong menolong dalam hal kebaikan. Misalnya, pada saat 
berkerjasama dalam kelompok dan pada saat guru meminta siswa untuk melaksanakan operasi semut. Hal ini sejalan dengan Mustari (2011:21) yang berpendapat bawah tanggung jawab adalah sikap dan prilaku seseorang untuk melaksanakan tugas dan kewajiban yang seharusnya dia lakukan terhadap diri sendiri, masyarakat, dan lingkungan.

Tanggung jawab merupakan kesadaran manusia akan perbuatan yang dilakukan berdasarkan kewajiban maupun panggilan hati seseorang. Dengan adanya tanggung jawab yang tinggi akan mendorong seseorang untuk bersungguhsungguh dalam melaksanakan dan menyelesaikan suatu pekerjaan dengan baik. Hal ini sejalan dengan penelitian yang dilakukan oleh Despa (2017), dalam penelitiannya menyatakan bahwa tanggung jawab merupakan kesadaran manusia akan tingkah laku atau perbuatan yang disengaja maupun tidak disengaja.Penerapan langkahlangkah model pembelajaran Learning Cycle dapat membuat siswa menjadi bertanggung jawab, hal ini terlihat pada saat pembelajaran berlangsung, siswa sudah mulai bertanggung jawab dengan tugas yang diberikan, siswa juga mengerjakan tugas dengan tepat waktu, dan bertanggung jawab dengan kebersihan kelas, hal ini sejalan dengan hasil penelitian Udayani (2014), dalam penelitiannya menyatakan bahwa Learning Cycle dapat melatih siswa unuk bertanggung jawab. Dengan penerapan langkah-langkah model Learning Cycle juga dapat melatih siswa menjadi aktif dan kreatif. Hal ini terlihat pada saat pembelajaran berlangsung, siswa sudah mulai aktif bertanya dan siswa juga tidak ragu-ragu menjawab pertanyaan dari guru, pada saat mengerjakan tugas kelompok siswa juga sudah mulai kreatif, siswa sudah berani mengeluarkan ide/ pendapat kepada teman kelompoknya. Hal ini sejalan dengan penelitian yang dilakukan oleh Elvionita (2019), dalam penelitiannya menyatakan bahwa model learning cycle membuat siswa dapat terlibat aktif dalam proses pembelajaran sehingga membentuk siswa yang aktif, inovatif dan kreatif serta pembelajaran menjadi lebih bermakna dan menyenangkan.

\section{Simpulan}

Berdasarkan hasil penelitian yang telah dilakukan dua siklus dengan menerapkan model pembelajaran Learning Cycle diambil kesimpulan sebagai berikut:

1. Pelaksanaan Model Pembelajaran Learning Cycle

Penerapan model pembelajaran Learning Cycle dapat meningkatkan tanggung jawab siswa. Hal ini dibuktikan dengan nilai rata-rata hasil observasi penerapan model Learning cycle siklus pertama ke siklus kedua. Siklus pertama rata-rata yang diperoleh 14,5 dengan kategori cukup, sehingga penelitian ini dilanjutkan pada siklus kedua. Pada siklus kedua skor rata-rata yang diperoleh 22 dengan kategori sangat baik dan sudah menunjukkan peningkatan sehingga penelitian ini tidak ditindaklanjuti lagi dan sudah berhasil.

2. Tanggung Jawab Siswa

Berdasarkan hasil penelitian yang telah dilaksanakan dapat disimpulkan

bahwa tanggung jawab siswa meningkat. Peningkatan tersebut terjadi pada setiap indikator tanggung jawab, dari siklus pertama ke siklus kedua. Hal ini ditunjukkan dengan adanya peningkatan hasil observasi tanggung jawab siswa pada siklus pertama diperoleh rata-rata 27,52 dengan kategori cukup, dan meningkat pada siklus kedua yaitu diperoleh rata-rata skor 38,45 dengan kategori sangat baik

\section{Saran}


Berdasarkan hasil penelitian yang telah dilakukan, peneliti mengemukakan beberapa saran sebagai berikut:

1. Guru disarankan untuk lebih memperhatikan pengelolaan kelas dan membimbing siswa dalam berdiskusi kelompok agar dapat mengkondisikan kelas dan kelas menjadi lebih kondusif.

2. Guru juga disarankan untuk selalu membiasakan siswa dan menanamkan sikap tanggung jawab kepada siswa agar siswa selalu bertanggung jawab terhadap apa yang dilakukannya.

\section{Referensi}

Despa Yulandari., 2017. Studi Deskriptif Tentang Pelaksanaan Baris Berbaris Pendidikan Kepramukaan Dalam Membentuk Karakter Bertanggung Jawab Siswa SD N 03 Kota Bengkulu, FKIP UNIB.

Dewi, F, P., 2016. Tingkat Tanggung Jawab belajar siswa kelas V SD Negeri 15 Yogyakarta Tahun Ajaran 2015/2016 dan Implementasinya Terhadap Usulan Topik-topik Bimbingan Belajar, FKIP Universitas Sanata Dharma, dipublikasikan.

Elvionita, Monica., 2019. Pengaruh Model Leraning Cycle Terhadap Hasil Belajar Siwa Pada Pembelajaran Tematik Di Kelas V SD Negeri Gugus 8 Kota Bengkulu, FKIP UNIB, dipublikasikan.

Lickon, Thomas., 2013. Pendidikan Karakter Panduan Lengkap Mendidik Siswa Menjadi Pintar Dan Baik. Bandung: Nusa Media.

Mohamad Mustari., (2014) Nilai Karakter Refleksi Untuk Pendidikan, Jakarta: PT. Raja Grafindo.

Ngalimun., (2018), Strategi dan Model Pembelajaran, Yogyakarta: Aswaja Pressindo.

Pinto, L.E. dkk. 2014. 95 Strategi Pengajaran. Jakarta: Indeks.

Saleh, Muwafik., (2012). Membangun Karakter Dengan Hati Nurani. Jakarta: Erlangga.

Shoimin, Aris., 2014. 68 Model Pembelajaran Inovatif dalam Kurikulum 2013, Yongyakrta: Ar-Ruuz Media.

Sudjana, Nana., (2009), Penilaian Hasil Proses Belajar Mengajar, Bandung: PT Remaja Rosdakarya.

Suyadi., (2013), Stategi Pembelajaran Pendidikan Karakter. Bandung: PT Remaja Rosolakarya.

Udayani, P. A., Kusmariyatni, N., \& Wibawa, I. M. C. (2014). Pengaruh Model Siklus Belajar (Learning Cycle 5E) terhadap Kemampuan Berpikir Kritis IPA Siswa Kelas IV SD di Desa Kalibukbuk. MIMBAR PGSD Undiksha, 2(1).

Ulfa, Dinia., 2014, Meningatkan Tanggung Jawab Siswa Belajar Dengan Layanan

Konseling Individual Berbasis Self-Management Pada Siswa Kelas XI SMK N 1

Palembang. Jurnal, FKIP Universitas Negeri Palembang, dipublikasikan

Winarni, E.W., (2018), Penelitian Kuantitatif Kualitatif, Jakarta: Bumi Aksara

Yaumi, Muhammad., 2014. Pendidikan Karakter Landasan Pilar dan Impleentasi. jakarta: Prenadamedia Group.

Zubaedi. 2011. Desain Pendidikan Karakter Konsepsi dan Aplikasinya dalam Lembaga Pendidikan. Jakarta: Kencana. 